\title{
The use of Lysol in Spanish Influenza
} post-pandemic times

\author{
Uso do Lysol em tempos pós-pandémicos da gripe espanhola \\ Uso del Lysol en tiempos pospandémicos de la gripe española
}

Mariana Antunes Knust ${ }^{1}$

(iD https://orcid.org/0000-0002-8936-7372

Keythluci Faria Trigueiro da Silva ${ }^{2}$

(iD https://orcid.org/0000-0002-2475-7388

Hugo Alberto Neves de Souza ${ }^{1}$

(iD https://orcid.org/0000-0002-0859-4654

Juliana Silva Corrêa Lourenço

de Cantuária Gama ${ }^{1}$

(iD https://orcid.org/0000-0002-7898-3241

Luiza Mara Correia ${ }^{3}$

(iD https://orcid.org/0000-0002-4660-2416

Mercedes Neto ${ }^{3}$

(iD https://orcid.org/0000-0001-7529-9535

Fernando Porto ${ }^{1}$

(iD https://orcid.org/0000-0002-2880-724X

${ }^{1}$ Rio de Janeiro State Federal University, Nursing School Alfredo Pinto, Rio de Janeiro - RJ, Brazil

${ }^{2}$ Hospital Samaritano Barra da Tijuca, Rio de Janeiro - RJ, Brazil

${ }^{3}$ State University of Rio de Janeiro, Faculty of Nursing, Rio de Janeiro - RJ, Brazil

Corresponding author

Mercedes Neto

E-mail: mercedesneto.uerj@gmail.com

Received: 24.08 .20

Accepted: 16.02 .21

\section{Abstract}

Background: During the post-Spanish Influenza pandemic period (in the 1920s), nursing manuals used in Brazilian nurses' training recommended Lysol as a hygiene product, a fact that, years later, led to the discussion on its use.

Objective: To discuss the content of nursing manuals regarding the recommendation of Lysol in association with the product's advertisements in a weekly social magazine and characterizing the culture of care at the time.

Methodology: Historical research using the microhistory approach. Data were collected from nursing manuals and the Digital Hemeroteca of the National Library, covering the period between 1920 and 1929. The data were analyzed using the microanalysis framework.

Results: Lysolwas used for washing hands and wounds and advertised using health professionals' images. Conclusion: This study contributes to building knowledge in different areas by associating the present with the past.

Keywords: influenza pandemic, 1918-1919; advertising; epidemics; hygiene; nursing

\section{Resumo}

Contexto: Durante o período de pandemia pós-influenza espanhola (na década de 1920), o lysol era uma das indicaçôes, como produto de higiene, nos manuais de enfermagem para a formação das enfermeiras brasileiras, o que anos mais tarde gerou discussão sobre a sua indicação.

Objetivo: Discutir o conteúdo dos manuais de enfermagem sobre a citação do lysol, articulando as peças publicitárias do produto num seminário veiculado na imprensa social, ao mostrar a cultura dos cuidados à época.

Metodologia: Investigaçâo histórica na perspetiva da microhistória. A colheita de dados foi realizada nos manuais de enfermagem e na Hemeroteca Digital da Biblioteca Nacional, com limitação nos anos de 1920 a 1929. Utilizou-se o referencial da microanálise para a análise dos dados.

Resultados: A aplicação do produto era usada para lavagem das mãos e feridas, divulgada pela imagem dos profissionais de saúde.

Conclusáo: Este estudo pode contribuir para a construção do conhecimento em diferentes áreas, articulando o presente e o passado.

Palavras-chave: influenza pandémica, 1918-1919; publicidade como assunto; epidemias; higiene; enfermagem

\section{Resumen}

Contexto: En el contexto de la pandemia de la gripe española (década de 1920), el Lysol se indicó como una de las medidas de higiene en los manuales de enfermería para la formación de las enfermeras brasileñas, lo que años más tarde llevó a que se discutiese aquella indicación.

Objetivo: Discutir el contenido de los manuales de enfermería sobre las citas al Lysol, articulando anuncios publicitarios del producto en un semanário realizado en la prensa social en el que se muestra la cultura del cuidado en aquella época.

Metodología: Investigación histórica desde la perspectiva de la microhistoria. Los datos se recopilaron de los manuales de enfermería y de la Hemeroteca Digital de la Biblioteca Nacional, y se limitaron al periodo comprendido entre 1920 y 1929. Para analizar los datos se utilizó el referente del microanálisis. Resultados: El producto se utilizó para el lavado de manos y heridas, que se divulgó con la imagen de los profesionales de la salud.

Conclusión: Este estudio puede contribuir a la construcción del conocimiento en diferentes áreas, así como a articular el presente y el pasado.

Palabras clave: influenza pandémica, 1918-1919; publicidad como asunto; epidemias; higiene; enfermería
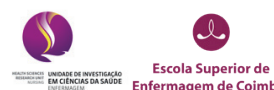

How to cite this article: Knust, M. A., Silva, K. F., Neves, H. A., Gama, J. S., Correia, L. M., Neto, M., \& Porto, F. (2021). The use of Lysol in Spanish Influenza post-pandemic times. Revista de Enfermagem Referência, 5(Supl. 8), e20142. https://doi.org/10.12707/RV20142 


\section{Introduction}

This study aims to analyze the indication of the use of Lysol in nursing manuals. The period chosen was the 1920 s, due to including the post-Spanish Influenza period, the development of the professionalization process in Brazilian nursing, and the implementation of modern nursing by North-American nurses during the Sanitary Reform, led by Carlos Chagas.

The study was geographically limited to the Federal district of Brazil's capital at the time, Rio de Janeiro.

It is worth mentioning that the decades preceding the 1920s were marked by several cultural, social, and sanitary aspects, particularly the French-influenced Belle Epoque, Brazil's participation in World War I as an ally of the United States, and the Spanish Influenza pandemic. These facts, directly or indirectly, promoted the triggering of events that influenced the (re)configuration of the country's public health culture, with the creation of the National Department of Public Health (created on January 2, 1920, by Decree no. 3.987), in the Federal District. Also, in the field of nursing, the following institutions and nursing degrees were created: the Escola Profissional de Enfermeiros e Enfermeiras (the Professional School of Nurses, 1890), currently known as the Escola de Enfermagem Alfredo Pinto (Nursing School Alfredo Pinto); the Escola Prática de Enfermeiras da Cruz Vermelha Brasileira (Practical School of Nurses of the Brazilian Red Cross, 1916), which included the Voluntary Nurses' Course (1914) and the Professional Nurses' Course (1916); and the Botafogo Polyclinic Nurses' Course (1919). Other education institutions dedicated to nursing education also had their programs. However, it was impossible to obtain enough data on their operation to include them in the study (Porto \& Amorim, 2010).

In this context, the evidence on the development of the culture of care suggests the French influence in the Escola Profissional de Enfermeiros e Enfermeiras and Escola Prática de Enfermeiras da Cruz Vermelha Brasileira, and the North-American influence in the Escola de Enfermeiras do Departamento Nacional de Saúde Pública (School of Nurses of the National Department of Public Health), in 1922 (Porto \& Amorim, 2010).

When searching for Lysol in nursing manuals and advertisements as a hygiene product, it was observed that it appears included with medicines and similar products in 1920's weekly publications (Silva et al., 2015).

This study uses Gonzáles' (2011) cultural approach regarding the use of mechanisms of transmission/communication of information and how this information should be analyzed and discussed as a sociocultural effect considering that each society has its own culture, plurality, and influences on the development of nursing care. This author also considers that one of the pillars of culture in every society is the meaning of health, illness, and reality applied to conceptual limits. This means that knowledge and action are the bases for developing nursing care in the health-illness process. Nevertheless, the essential needs, rites, and beliefs that revolve around the development of culture must also be considered.
Manuals and advertisements are historical sources that show the culture of care taught to nurses and intended for use in society. The manuals were understood as one of the anthropology-based elements for the formation of the culture of care and the understanding of culture (Laraia, 2002).

The conceptual association between the manuals and culture supports the research by addressing the influence of habits and customs. This allows understanding the learning process because it is one of the forms of transmission/communication of knowledge in the teaching process of Brazilian nursing education.

The objective of this study was to discuss the content of nursing manuals regarding Lysol, using the product's advertisements on a weekly social magazine to characterize the culture of care at the time.

\section{Methodology}

This study is based on the microhistory perspective (Ginzburg, 1998). The sources for the construction of the study were nursing manuals and Lysol advertisements from a weekly publication. The nursing manuals were selected according to the following criteria: they had to be written in Portuguese and published in the 1920s. A weekly magazine was chosen to identify Lysol advertisements. The data were collected between May and June 2020. For the nursing manuals, the SOPHIA database of the Central Library of UNIRIO, in the room Guilherme Figueiredo, was used, and the Digital Hemeroteca of the National Library was used for identifying Lysol advertisements published in a weekly magazine, from 1920 to 1929.

Targeted readings regarding the administration and use of medication or similar were established for the selected manuals. A collection instrument was created for the advertisements, consisting of information on the date, edition, page, and a summary of the advertisement message and illustration for analysis and subsequent discussion. Based on the results, the data were sorted for analysis, which occurred according to the literature, both for the manuals and the advertisements.

The data were organized in two representative tables manuals and advertisements. These tables present the excerpts mentioning the product in the manuals, as well as regarding the weekly social magazine, the advertisements and their respective summaries, year of publication, and frequency of occurrence, which this study analyzed and discussed to prepare the final considerations.

\section{Results and Discussion}

Based on the established criteria, two manuals were selected, one by Adolpho Possollo and the other by Getúlio dos Santos, and the selected weekly publication was the Revista da Semana.

Adolpho Possollo was a physician, head of the surgery service at the Ambulatório Rivadavia Corrêa, professor of Surgical Clinic at the Rio de Janeiro Medical School, 
medical captain of the Rio de Janeiro State Police Department (1892-1893), and surgeon of the Rio de Janeiro Trade Employees Association (1903-1910).

Adolpho Possollo's work, entitled Curso de Enfermeiros (Course for Nurses), had its first edition in 1920 and continued until 1942, with seven (re)editions and including the latest information at that time. The 1920 edition was composed of 147 pages, with a preface on the history of the first three teaching institutions in favor of nursing professionalization in the Federal District - Escola Profissional de Enfermeiros e Enfermeiras (1890), Escola Prática de Enfermagem da Cruz Vermelha Brasileira (1916), and Curso de Enfermeiras da Policlínica de Botafogo (1917), with 345 illustrations, ten sections/chapters, and works published by the author. During the reading, the term Lysol appeared once, as shown in Table 1, in the section/ chapter entitled "Dressings and Minor Surgery."

As shown in Table 1, the product was indicated for hand washing and wound care. Thus, the route of administration was topical by nature, which was possibly suggested by the image on the packaging, which was not available. The absence of illustrations may be due to the direct commercialization of the product, a situation that may have passed unnoticed to the readers at the time. On the other hand, it seems that the product's mention was also common practice and part of society's cultural knowledge.

\section{Table 1}

Lysol quoted in Adolpho Possollo's work (1920)

\begin{tabular}{lcc}
\hline \multicolumn{1}{c}{ Description } & Route of administration & Illustrations \\
\hline $\begin{array}{l}\text { "Lysol is used in a } 10 \% \text { or } 20 \% \text { solution for handwashing and, in weaker solutions, for } \\
\text { wound washing." }\end{array}$ & Topical & No illustration \\
\hline
\end{tabular}

Getúlio dos Santos (1881-1928), was the director of the Escola Prática de Enfermeiras da Cruz Vermelha Brasileira and a graduate of the Rio de Janeiro Medical School with a military background. He was also General Secretary and Director of the Medical Institute (Santos, 1928). His manual, entitled "Livro do Enfermeiro e da Enfermeira para uso dos que se destinam a profissão de enfermagem e das pessoas que cuidam de doentes" (The Nurse's Book - for the use of those in the nursing profession and those who care for the sick) had its first edition in 1916 and the third one in 1928. The last edition was 376 pages long, with a preface to the previous editions, 151 illustrations, 13 sections/chapters, and, in the end, a presentation of some recurrent surgical and medical technical terms, the most common pharmaceutical preparations, an index of chapters and illustrations, and an errata. During the reading, the term Lysol was not found.

The weekly publication selected was Revista da Semana (Weekly Magazine). It was created in 1900 and circulated until 1959, composed of articles full of pictures - facsimiles - of social events, short stories, advertisements, and propaganda. At the time, it was considered light reading for women.
The Revista da Semana was a weekly magazine, with a total of 52 to 53 copies per year, costing $1 \$ 200$ réis per magazine, which, at the time, corresponded approximately to the purchase of a dozen eggs.

Eleven advertisements were identified for Lysol, both in the soap or liquid version, from 1921 to 1929, as presented in Table 2.

A total of 11 advertisements were found, of which one was for a bar of Lysol soap, one for Lysol shaving cream, and nine for Lysol bottles. The advertisements for the liquid version of Lysol stand out as they were more elaborate than the others, featuring pictures of women who appear to be nurses due to their veil and cap or housewives. Some of these advertisements also feature children, a man who appears to be a doctor, and a dog.

In the nine advertisements, the product layout was presented to the potential buyer to visually identify the product and act as a mental trigger at the moment of purchase. However, the cost of the product was not mentioned in the advertisements. Nevertheless, it is believed that publishing 52 advertisements over ten years is a good way of promoting the product's use in society. 
Table 2

Lysol advertisements in the Revista da Semana during the 1920s

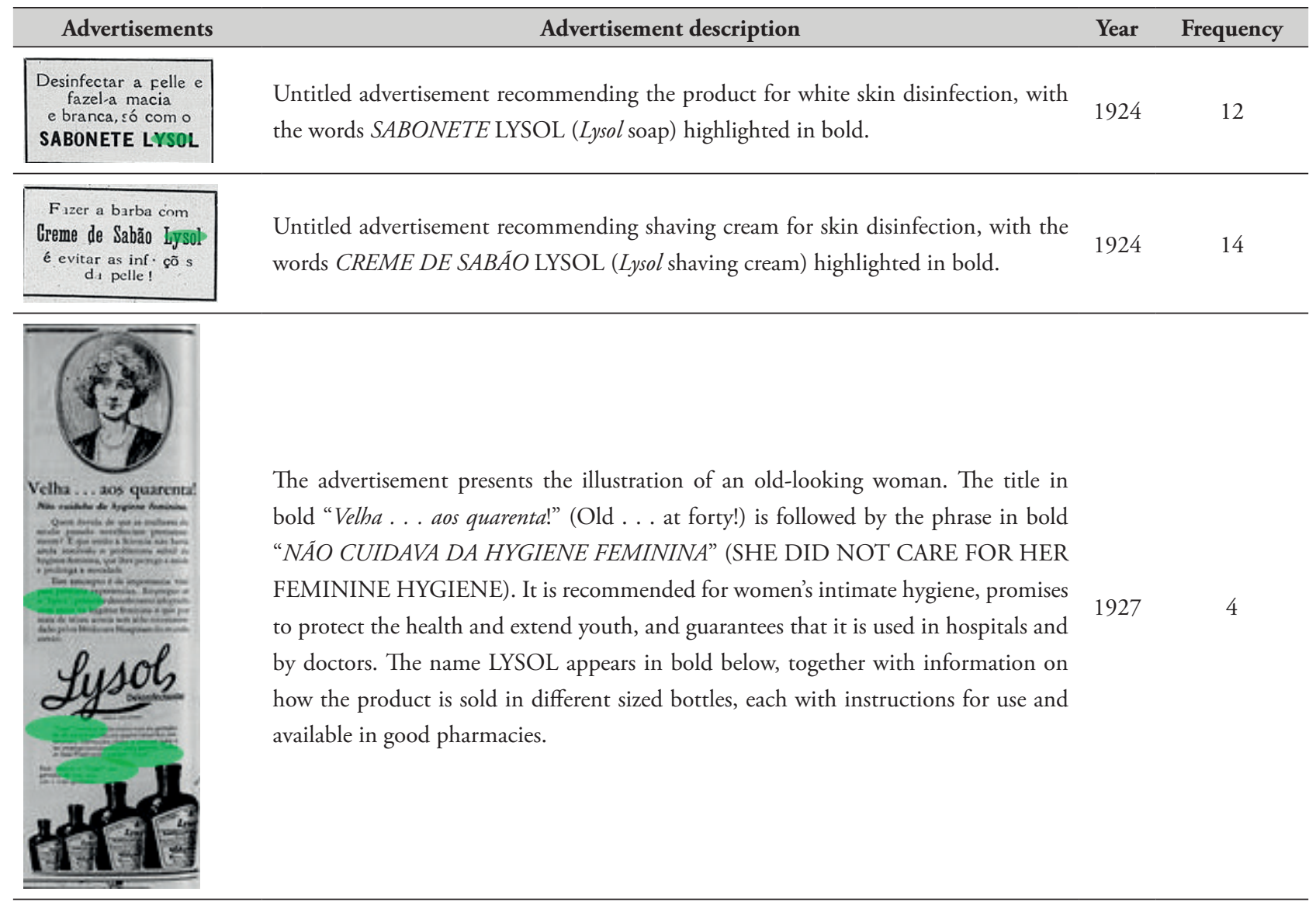

The advertisement presents the illustration of a young woman sitting with a book in
her hand. The title in bold "Aproveite a mocidade" (Enjoy your youth) is followed by
the phrase in bold "CUIDE DA HYGIENE PESSOAL" (TAKE CARE OF YOUR
PERSONAL HYGIENE). The product is recommended for women's feminine hy- 1927
giene. It promises health protection and youth extension and guarantees that it is
used in hospitals and by reliable doctors. It comes in different-sized bottles, each with
instructions for use. The product is available in good pharmacies.



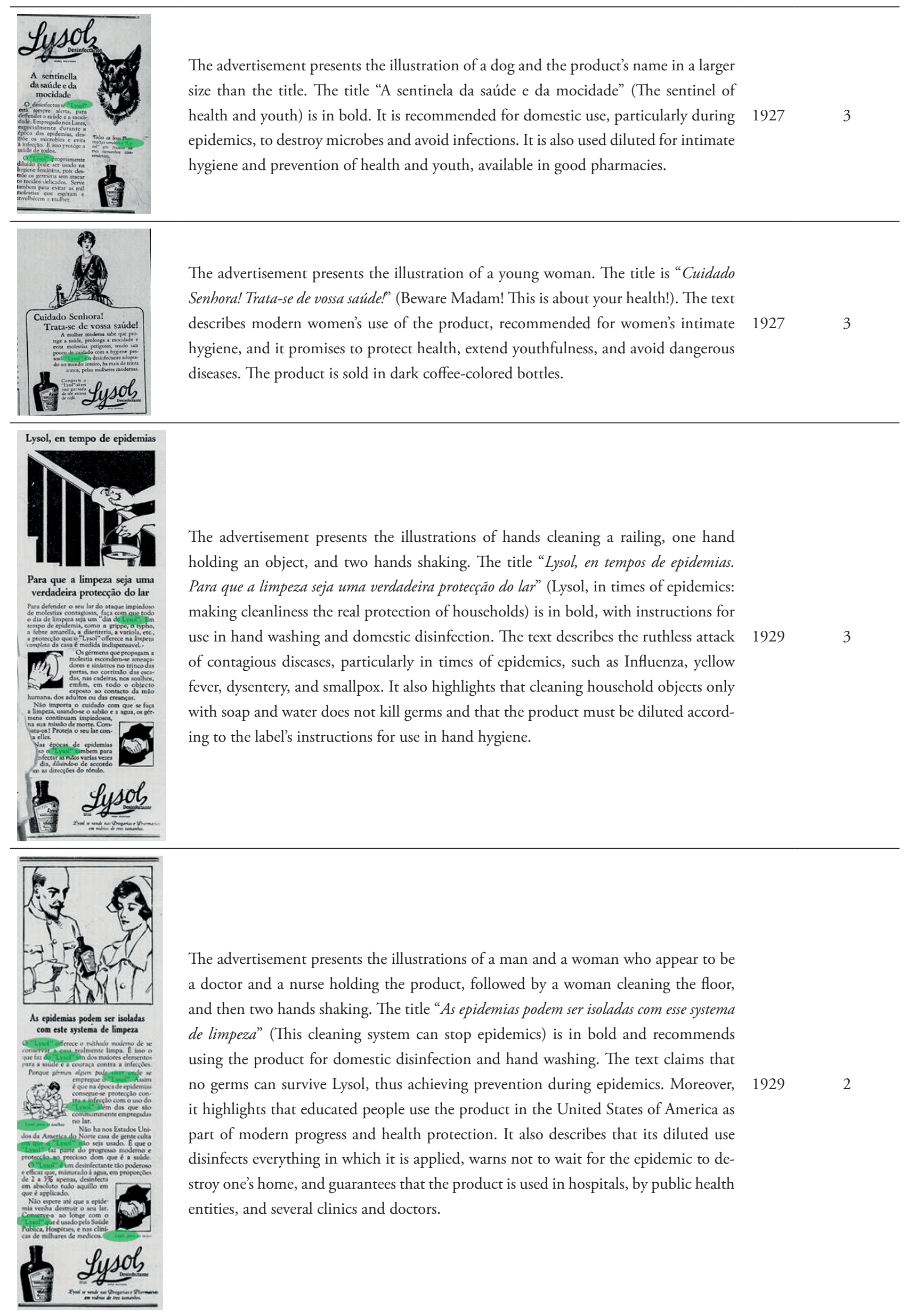

The advertisement presents the illustrations of a man and a woman who appear to be a doctor and a nurse holding the product, followed by a woman cleaning the floor, and then two hands shaking. The title "As epidemias podem ser isoladas com esse systema de limpeza" (This cleaning system can stop epidemics) is in bold and recommends using the product for domestic disinfection and hand washing. The text claims that no germs can survive Lysol, thus achieving prevention during epidemics. Moreover, it highlights that educated people use the product in the United States of America as part of modern progress and health protection. It also describes that its diluted use disinfects everything in which it is applied, warns not to wait for the epidemic to destroy one's home, and guarantees that the product is used in hospitals, by public health entities, and several clinics and doctors. 


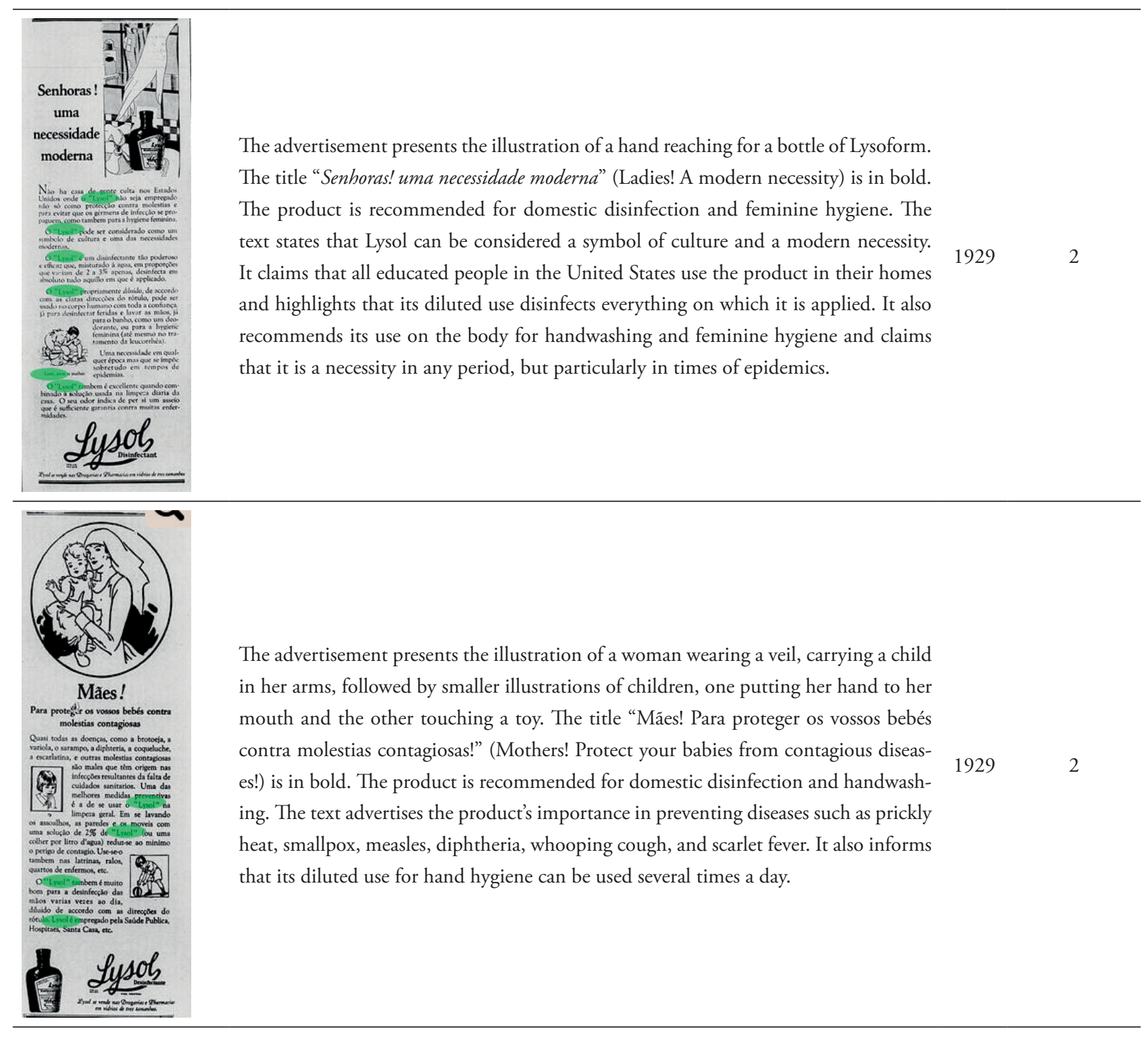

These Lysol advertisements circulated in the media during the Spanish Influenza post-pandemic period, at the beginning of the Sanitary Reform, led by Carlos Chagas, in the Federal District, to fight particularly against Tuberculosis. Lysol was originally produced by a German company established in 1889, which introduced the product on the market as the first modern disinfectant. In 1890, the product began to be imported by American company Lehn \& Fink, expanding its consumption, and used in hospitals and factories. In 1918, it was widely used in Germany during the Spanish Influenza pandemic, becoming one of the most popular and representative products in the growth of trade and marketing. In 1922, after World War I, Lehn \& Fink obtained control of Lysol and started producing it. In 1994, the British company Reckitt Benckiser bought the American company and added Lysol to its list of products, where it remains until today (Araujo, 2020).

The products were recommended to disinfect environments, skin, and even in women's intimate hygiene to remove vaginal odors. However, its indication as a contraceptive was controversial. This is due to the combination of phenolic chemical compounds in a soap solution made from potassium hydroxide and linseed oil, which has disinfecting and antiseptic properties (Araujo, 2020). Associating the indication of the product in Adolpho Possollo's work with Lysol advertisements implies relying on nurses' image and that of other health professionals for building the product's credibility in the consumer's eyes. The use of health professionals' images, at first glance, is due to the association with disinfection, but further exploration of the arguments is needed to understand better the mental engineering applied to the advertisements. This leads back to the end of the 1910s, when the Spanish Influenza pandemic occurred and when the media, such as newspapers and weeklies, explored the facts/events to inform society about what was happening in the streets, health institutions, public policies, among others that could be associated to the sanitary problem the Federal District was going through.

Considering this perspective, it is important to bring to light other studies on the period when nurses and doctors dedicated themselves to fighting the Spanish Influenza pandemic.

The proposals made by the hygienists at the time (Carlos Chagas and Oswaldo Cruz) to fight the Influenza had to 
be negotiated because they were seen as aggressive measures with repercussions in the social and political spheres. Nevertheless, gradually, the hygienists won recognition (Goulart, 2005).

As actions were implemented at a slow pace, urban sanitation was ineffective, and public health policies were weak, the Spanish Influenza was lethal in Brazil and brought important implications for the social, cultural, and political contexts (Neto \& Porto, 2019). By bringing up these studies, this research aims to approach society's mentality at the time when hygiene measures saved thousands of people, which in the social imaginary is associated with the image of nurses and other health professionals. In the 1920s in Brazil, the adherence to hygiene with the application of the Sanitary Reform reduced the cases of Tuberculosis, which was epidemic.

To think about the Tuberculosis epidemic in the Federal District is to remember that nurses, whether from the Cruz Vermelha Brasileira (Brazilian Red Cross) or the National Department of Public Health, were engaged in the fight against Tuberculosis.

Ayres (2010) calls attention to the Enfermeiras Visitadoras (Visiting Nurses) of the Cruz Vermelha Brasileira (1919-1921), who worked first in the Spanish Influenza pandemic and then in the National Campaign to Fight Tuberculosis, under the leadership of Dr. Amaury de Medeiros, Director of the Hospital da Cruz Vermelha Brasileira. These nurses and the nurses trained by the Nursing School of the National Department of Public Health visited the homes of those affected by Tuberculosis to promote health awareness. The nurses performed several functions, from early detection of tuberculosis suspects to ensuring compliance with sanitary norms for disease prevention, such as disinfection of environments.

At the time, particularly in the early 1920s, the Revista da Semana announced the creation of the Nursing School of the Department of Public Health, during the training of the Visitadoras de Higiene, who would be replaced years later (1925) by the nurses trained by this institution, and reported that these events marked a new era of hygiene in the capital of Brazil (Porto \& Santos, 2008). This may be associated with Brazil's Independence Centennial (1922) festivities, having been used as a display window of the country's modernity to the world.

Another study, which reports on the micro context in association with the macro context, deals with the nurses' performance in private and institutional spaces in the fight against Tuberculosis by highlighting that the professionalization model of the National Department of Public Health was based on the feminization of care (Deslandes, 2012). This reaffirms the use of nurses' image in advertisements as the holders of care knowledge. For Natalino and Arcioni (2019), women's entry into the labor market in the 1920s caused changes in advertising due to their newly acquired purchasing power. Soon, women became the target audience of the campaigns as they worked and continued to care for their homes and families.

To think about these historical arguments is to use the credibility of nurses' image as advertising messengers who support the consumption of Lysol. Thus, the advertisements associated with Adolpho Possollo's work are understood as (in)conscious mental triggers for selling the product. Possollo's work recommended using Lysol in hand washing and wound care, thus confirming that the product was intended for care, hygiene, and health. It is a mental trigger used as a strategy, applying the technique of attention, interest, desire, and action (AIDA). This is a communication technique created by the American E. K. Strong at the beginning of the twentieth century, based on the theory that to sell a certain product, for example, it is necessary to capture a person's attention, interest, and desire to produce an action (Rosa \& Cunha, 1999). Using this logic in advertisements allowed the reader to understand that the product was not based on pseudo-information, currently known as fake news (Neto et al., 2020). Contrary to what many may think, this implied the circulation of news that promised a certain success, as it occurred during the Spanish Influenza, when they were published in the press (Albuquerque, 2020). Understanding the mechanisms that operate the media is relevant for associations, whether in pandemic or pos$\mathrm{t}$-pandemic times. Thus, in one of the advertisements, the expression "Lysol, in times of epidemics" and "This cleaning system can stop epidemics" are significant, as well as others that can be associated with the 1920s modernity context, such as: "Ladies! A modern necessity".

\section{Conclusion}

By understanding the content of nursing manuals and advertisements mentioning Lysol, it is possible to observe the construction of the culture of care that, using communication media, establishes social customs and behaviors. Moreover, the analysis and discussion carried out in this study can add to the construction of knowledge in nursing and health, particularly by understanding the different areas of knowledge, as well as understanding the mechanism in the present and how Lysol advertisements worked in the past. Today, Lysol is once again being advertised in television commercials due to the COVID-19 pandemic, a period when hygiene offers potential audience and consumer effect. However, the company warns against using it in the human body.

One of this study's limitations is the lack of analysis of the illustrations' outline, their arrangement on the page of the Revista da Semana, and their layout, which could bring other versions and interpretations into the discussion.

\section{Author contributions}

Conceptualization: Correia, L. M., Neto, M., Porto, F. Data curation: Knust, M. A., Silva, K. F., Souza, H. A., Gama, J. S.

Formal analysis: Knust, M. A., Silva, K. F., Souza, H. A., Gama, J. S.

Funding acquisition: Knust, M. A., Silva, K. F., Souza, H. A., Gama, J. S.

Investigation: Knust, M. A., Silva, K. F., Souza, H. A., Gama, J. S. 
Methodology: Souza, H. A., Gama, J. S., Correia, L. M., Neto, M., Porto, F.

Supervision: Correia, L. M., Neto, M., Porto, F. Validation: Correia, L. M., Neto, M., Porto, F.

Visualization: Correia, L. M., Neto, M., Porto, F. Writing - original draft: Correia, L. M., Neto, M., Porto, F.

Writing - review \& editing: Neto, M., Porto, F.

\section{References}

Albuquerque, C. (2020). Fake news circularam na imprensa na epidemia de 1918.

http://www.revistahcsm.coc.fiocruz.br/fake-news-circularam-na-imprensa-na-gripe-espanhola-em-1918/

Araujo, J. C. (2020) Lysol: o desinfetante que já foi usado como método contraceptivo. Disponível em: https://www.megacurioso.com. br/estilo-de-vida/117066-lysol-o-desinfetan te-que-ja-foi-usado-como-metodo-contraceptivo.htm. Acessado em: 20 mar 2021

Ayres, L. F. (2010). As enfermeiras visitadoras da Cruz Vermelha Brasileira e do Departamento Nacional de Saúde Pública no início do século XX [Dissertação de Mestrado, Universidade Federal do Estado do Rio de Janeiro]. Hórus - Repositório Institucional da UNIRIO. http://www.unirio.br/ppgenf/dissertacoes/dissertacoes-ppgenf-unirio-ano-2010/dissertacao-lilian-fernandes-arial-ayres

Deslandes, A. K. (2012). Cuidado e enfermeiras na revista da semana no âmbito da reforma sanitária [Dissertação de Mestrado, Universidade Federal do Estado do Rio]. Hórus - Repositório Institucional da UNIRIO.http://www.repositorio-bc.unirio.br:8080/xmlui/ handle/unirio/12119

Ginzburg, C. (1998). A micro-história e outros ensaios. Difel, Bertrand Brasil.
Gonzáles, J. S. (2011). História de la enfermería. Difisión Avances de Enfermería.

Goulart, A. D. (2005). Revisitando a espanhola: A gripe pandêmica de 1918 no Rio de Janeiro. História, ciências, saúde-Manguinhos, 12(1), 101-142. https://doi.org/10.1590/S0104-59702005000100006

Laraia, R. B. (2002). Cultura: Um conceito antropológico. Zahar.

Natalino, L. R., \& Arcioni, W. A. (2019, Junho 3-5). A reprodução do estereótipo feminino "rainha do lar" na publicidade [Comunicação]. XXIV Congresso de Ciências da Comunicação na Região Sudeste, Vitória, Brasil. https://portalintercom.org.br/anais/sudeste2019/ resumos/R68-1084-1.pdf

Neto, M., \& Porto, F. (2019). O que o passado tem a nos ensinar sobre a Influenza? Revista Enfermagem UERJ, 27, e40236. https:// www.e-publicacoes.uerj.br/index.php/enfermagemuerj/article/ view/40236

Neto, M., Gomes, T. O., Porto, F. R., Rafael, R. D., Fonseca, M. H., \& Nascimento, J. (2020). Fake news no cenário da pandemia de Covid-19. Cogitare Enfermagem, 25. http://dx.doi.org/10.5380/ ce.v25i0.72627

Porto, F., \& Amorim, W. M. (2010). Escolas e cursos de enfermagem na história da profissão no brasil (1890-1922). Revista Cultura de Los Cuidados, 14(27), 40-45. https://rua.ua.es/dspace/bitstream/10045/14388/1/CC_27_05.pdf

Porto, F., \& Santos, T. C. (2008). A enfermeira brasileira na mira do click fotográfico. In: F. Porto \& W. Amorim (Orgs.). História da enfermagem Brasileira: Lutas, ritos e emblemas. Águia Dourada.

Rosa J. A., \& Cunha T. C. (1999) Jornal de empresa: Criação, elaboração e administração. STS.

Santos, G. F. (1928). O livro do enfermeiro e da enfermeira. Est. Graphico. Silva, K. F., Villela, D. D., Risi, L., Rocha, J. A., \& Porto, F. (2015). Imagem da enfermeira nas publicidades de remédios no Brasil (1916-1931). Revista de Enfermagem Referência, 4(7), 123-128. https://doi.org/10.12707/RIV15053 